\title{
Öğretmen Adaylarının Orantısal Olan ve Olmayan İlişkileri Belirleyebilme ve Temsil Edebilmelerinin Problem İçerikleri Açısından Íncelenmesi
}

\author{
Muhammet ARICAN ${ }^{1}$ \\ ${ }^{1}$ Kırşehir Ahi Evran Üniversitesi, Matematik ve Fen Bilimleri Eğitimi Bölümü, \\ muhammetarican@gmail.com, http://orcid.org/0000-0002-0496-9148
}

Gönderme Tarihi: 03.02.2020

Kabul Tarihi: 15.06 .2020

Doi: $10.17522 /$ balikesirnef.683225

Özet - Bu çalışmada, 46 ortaokul matematik öğretmen adayının çözüm yöntemleri, orantısal olan ve olmayan ilişkileri belirleyebilmeleri ve temsil edebilmeleri problem içerikleri bağlamında incelenmiştir. Öğretmen adaylarına, 2017 ve 2018 güz dönemlerinde, iki adet sorudan oluşan bir kağıt-kalem testi verilmiştir. Adayların kağıt-kalem testine verdikleri cevaplar içerik analizi yöntemi kullanılarak analiz edilmiştir. Analizler sonucunda sekiz öğretmen adayı ile yarı yapılandırılmış görüşmeler gerçekleştirilmiştir. Elde edilen bulgular, öğretmen adaylarının çözüm yöntemlerinin ve orantısal olan ve olmayan ilişkileri belirleyebilmelerinin ve temsil edebilmelerinin problem içeriklerinden etkilendiğini göstermiştir. Alan yazında belirtilenin aksine, öğretmen adayları ters orantılı ilişkiyi belirleme ve temsil etme konusunda doğru orantılı ilişkiyi belirleme ve temsil etmeye göre daha başarılı olmuşlardır. Öte yandan, adaylar en çok orantısal olmayan ilişkinin belirlenmesi ve temsil edilmesinde zorlanmışlardır. Derinlemesine inceleme gerektiren problemler daha gelişmiş çözüm yöntemlerinin ortaya çıkmasını sağlayıp, öğretmen adaylarının ezbere hesaplamaları kullanmaktan kaçınmasına yardımcı olmuştur.

Anahtar kelimeler: matematiksel temsiller, orantısal akıl yürütme, orantısal ilişkiler, öğretmen adayları, problem içeriği.

Sorumlu Yazar: Muhammet ARICAN, Matematik ve Fen Bilimleri Eğitimi Bölümü. Bu çalışma Kırşehir Ahi Evran Üniversitesi Bilimsel Araştırma Projeleri Koordinasyon Birimi tarafından EGT.A4.18.014 proje numarası ile desteklenmiştir. Bu çalışmanın verileri 2017 ve 2018 yıllarında toplanmış olup, bir kısmı 19-22 Haziran 2019 tarihleri arasında Ankara'da düzenlenen VI. Uluslararası Avrasya Eğitim Araştırmaları Kongresinde sözlü bildiri olarak sunulmuştur. Dr. Wim Van Dooren ve Dr. Lieven Verschaffel'e bu çalışmaya dair verdikleri değerli geri bildirimleri için teşekkür ederim. 


\section{Geniş Özet}

Giriş

Oran, orantı ve orantısal ilişkileri anlamak okul matematiğinin önemli bir parçasını oluşturmaktadır (Lamon, 2007; Lobato \& Ellis, 2010). Ayrıca, bu kavramlar ortaokul matematiğinde öğrenilmesi en zor kavramlar olarak kabul edilmektedir (Arican, 2019; Izsák \& Jacobson, 2017; Lamon, 2007). Oransal akıl yürütme “orantısal ilişkilerin tanımlanması, temsil edilmesi, analiz edilmesi, açıklanması ve bu ilişkilere dair kanıt sunulması” olarak tanımlanmaktadır (Lamon, 2007, s. 647). Orantısal akıl yürütme, bilim ve günlük yaşamdaki birçok durumu anlamada önemli bir kavram olup (Cramer \& Post, 1993), öğrencilerin okul aritmetiği ve daha ileri matematiklerinin gelişiminde önemli bir role sahiptir (Kilpatrick, Swafford, \& Findell, 2001; Ulusal Matematik Öğretmenleri Konseyi [NCTM], 2000).

Öğrencilerin ve öğretmen adaylarının orantı problemlerini çözme ve orantısal ilişkileri belirleme ve temsil etmede yaşadıkları zorluklar birçok çalışma tarafından rapor edilmiştir (örn., Arican, 2019; Fisher, 1988; Izsák \& Jacobson, 2017; Johnson, 2017; Lim, 2009 ; Modestou \& Gagatsis, 2007). Araştırmacılar, kullanılan problem içeriğinin öğrencilerin yöntem seçimleri, matematiksel yeterlilikleri ve toplamsal veya çarpımsal akıl yürütme tercihleri üzerindeki etkilerini bildirmişlerdir. Diğer taraftan, alan yazında, problem içeriğinin öğretmen adaylarının çözüm stratejileri ve orantısal olan ve olmayan ilişkileri belirleyebilmeleri ve temsil edebilmeleri üzerindeki etkilerine dair yeterli bilgi yoktur. $\mathrm{Bu}$ nedenle, bu çalışmanın amacı orantısal olan ve olmayan problemlerde kullanılan içeriğin adayların yöntem seçimlerini ve verilen ilişkileri belirleyebilmelerini ve temsil edebilmelerini nasıl etkilediğini derinlemesine incelemektir. Ayrıca, bu çalışmadan elde edilen sonuçlar, öğretmen adaylarının oran, orantı, ve orantısal ilişki kavramlarının öğretimi için ihtiyaç duydukları matematik içerik bilgilerinin (Ball, Thames, \& Phelps, 2008) yeterlilikleri hakkında eğitimcilere geribildirim vermesi açısından önemlidir. Bu çalışmada aşağıdaki problem durumları incelenmiştir:

1. Oran-orantı problemlerinde kullanılan içerik ortaokul matematik öğretmenlerinin yöntem seçimlerini nasıl etkilemektedir?

2. Oran-orantı problemlerinde kullanılan içerik ortaokul matematik öğretmenlerinin orantısal olan ve olmayan ilişkileri belirleyebilmelerini nasıl etkilemektedir?

3. Oran-orantı problemlerinde kullanılan içerik ortaokul matematik öğretmenlerinin orantısal olan ve olmayan ilişkileri temsil edebilmelerini nasıl etkilemektedir? 
4. Ortaokul matematik öğretmenlerinin oran-orantı problemlerini çözerken ve orantısal olan ve olmayan ilişkileri belirlerken ve temsil ederken karşılaştıkları zorluklar nelerdir?

\section{Metot}

$\mathrm{Bu}$ çalışmada, açıklayıcı çalışma tasarım modeli takip edilmiştir (Fraenkel \& Wallen, 2006). Açıklayıcı çalışma tasarım modeli, araştırmacıların olayları daha etkin bir şekilde anlamalarına yardımcı olduğundan ve verileri analiz ederken hem nicel hem de nitel yöntemlere izin verdiğinden tercih edilmiştir. Bu çalışmaya 46 öğretmen adayı katılmış olup, adayların seçiminde amaçlı örneklem tekniği (Patton, 2005) izlenmiştir. Öğretmen adaylarına içerisinde çeşitli orantı problemleri içeren iki adet sorudan (Bisiklet ve Mum) oluşan bir kağıtkalem testi uygulanmıştır. Bisiklet sorusu, dört adet doğru ve ters orantı problemi ile iki adet bu ilişkilerin belirlenip temsil edilmesini içeren sorulardan oluşmuştur. Adaylar farklı büyüklükteki iki bisikletin teker büyüklükleri ve dönme sayıları arasındaki ters orantılı ilişki ve çark büyüklükleri ve etraflarında yer alan diş sayıları arasındaki doğru orantılı ilişkiyi incelemişlerdir. Mum sorusu Lim (2009) çalışmasından uyarlanmış olup, bir doğru orantı problemi ile bir orantısal olmayan problem içerip, adaylar bir mumun yanan kısmının uzunluğu ile geçen zaman arasındaki doğru orantılı ilişkiyi ve iki özdeş fakat farklı zamanlarda ateşlenmiş iki mumun boyları arasındaki toplamsal ilişkiyi incelemişlerdir. Adaylara soruları cevaplamaları için 50 dakika süre verilmiş olup, adayların kağıt-kalem testine verdikleri yazılı cevaplar içerik analizi yöntemi kullanılarak analiz edilmiştir. Analizler sonucunda sekiz öğretmen adayı ile yarı yapılandırılmış görüşmeler gerçekleştirilmiştir.

\section{Bulgular}

Adayların cevapları incelendiğinde, en başarılı oldukları problemin Mum sorusundaki doğru orantı problemi olduğu görülmüştür, 44 aday (\%95.7) doğru cevap verebilmiştir. Ayrıca, 36 aday (\%78.3) Bisiklet sorusunda küçük bisikletin tur sayısını doğru hesaplayabilmiştir. Adaylar en çok Bisiklet sorusunda alınan mesafeyi hesaplamada ve Mum sorusundaki toplamsal ilişki içeren problemde zorlanmışlardır. Mum sorusunda orantısal olmayan toplamsal ilişkiyi 16 aday $(\% 34,78)$ doğru orantılı ilişski ile karıştırıp yanlış sonuç elde etmişlerdir. Adayların çözüm yöntemleri incelendiğinde, daha çok içler-dışlar ve yanyana çarpma gibi mekanik yöntemlere başvurdukları gözlenmiştir.

Bisiklet sorusunda 27 aday $(\% 58,7)$ teker boyutları ile pedal sayısı arasındaki ters orantılı ilişkiyi belirleyebilmiş olup, sadece 15 aday $(\% 32,6)$ bu ilişkiyi doğru şekilde temsil edebilmiştir. Diğer taraftan, adayların sadece $14(\% 30,4)$ tanesi çarkların boyutları ile 
etraflarındaki diş sayısı arasındaki doğru orantılı ilişkiyi belirlemiş ve yalnız sekiz aday $(\% 17,4)$ bu ilişkiyi uygun matematiksel model kullanarak temsil edebilmiştir. Mum sorusunda, 34 aday $(\% 73,4)$ bir mumun yanmış kısmının uzunluğu ile bu parçanın yanması için geçen süre arasındaki doğru orantılı ilişkiyi belirleyebilmiş fakat sadece 16 aday $(\% 34,8)$ bu ilişkiyi temsil edebilmiştir. Son olarak, Mum sorusunda yalnızca dokuz $(\% 19,6)$ aday mumların yanan kısımlarının uzunlukları arasındaki toplamsal ilişkiliyi belirleyebilmiş ve bunların sekizi $(\% 17,4)$ bu ilişkiyi temsil edebilmiştir. Adaylar ile gerçekleştirilen yarıyapılandırılmış görüşmeler, adayların orantısal olan ve olmayan ilişkileri belirleme ve temsil etmede yaşadıkları zorlukları gözler önüne sermiştir.

\section{Sonuçlar ve Tartışma}

Adayların çözüm yöntemleri incelendiğinde Bisiklet sorusundaki ilk iki problem haricinde daha çok içler-dışlar ve yan-yana çarpma gibi mekanik yöntemlere başvurdukları görülmüştür. $\mathrm{Bu}$ iki bisiklet problemi içerik olarak adayların doğrudan formülleri kullanmaları yerine daha derinlemesine incelemeye firsat vermiştir. Bu nedenle, mekanik yöntemler yerine daha gelişmiş çözüm yöntemlerinin ortaya çıkmasını sağlayıp, öğretmen adaylarının ezbere hesaplamaları kullanmaktan kaçınmasına yardımcı olmuştur. Bisiklet sorusunda, adaylar alan yazında genel olarak kabul edilenin aksine doğru orantılı ilişkiyi belirleme ve temsil etmede ters orantıya oranla daha fazla zorluk yaşamışlardır. Adayların bu iki ilişkinin belirtildiği problem içeriğine alışık olup olmamaları bu sonucun bir nedeni olarak gösterilebilir. Görüşmelerde adaylar teker dönme sayıları ve büyüklükleri arasındaki ters orantılı ilişkiyi günlük yaşamdaki traktörlerin ön ve arka tekerlerin dönme sayıları örneğinden yola çıkarak açıklamaya çalışmışlardır. Ayrıca, bir aday buna benzer soruları Fizik dersinde öğrendiklerini bahsetmiştir. Diğer taraftan, çark büyüklüğü ve diş sayısı örneği ise adayların günlük yaşamlarında veya derslerde daha az rastladıkları bir durumdur.

Bisiklet ve Mum sorularında yer alan doğru orantılı ilişkiler karşılaştırıldığında, adaylar Mum sorusunda yer alan doğru orantılı ilişkiyi Bisiklet sorusuna oranla daha kolay tespit etmişlerdir. Buna rağmen pek çok aday mumun yanan miktarının uzunluğu ile zaman arasındaki doğru orantılı ilişkiyi uygun matematiksel model ile temsil etmede zorlanmıştır. Adayların orantısal olan ve olmayan ilişkileri temsil etme konusundaki zorlukları, bu ilişkiler hakkında geçmişte ortaokul ve liselerde almış oldukları ezbere dayalı öğretim ile ilişkilendirilebilir. Adaylara içerik olarak zengin problemler verip, bu problemlerde yer alan matematiksel ilişkileri çoklu temsiller ile göstermeye teşvik etmek orantısal akıl yürütmelerinin gelişimine katkı sağlayabilir (Lo, 2004). Adayları çözümlerinde çoklu 
temsiller kullanmaya teşvik etmek, oran, orantı ve orantısal ilişki gibi kavramlarla ilgili karşılaştıkları zorlukların üstesinden gelmeye yardımcı olabilir (Johnson, 2017). 


\title{
Investigating Preservice Teachers' Determination and Representation of Proportional and Nonproportional Relationships in Terms of Problem Contexts
}

\author{
Muhammet ARICAN ${ }^{1}$ \\ ${ }^{1}$ Kırşehir Ahi Evran University, Mathematics and Science Education Department, \\ muhammetarican@gmail.com, http://orcid.org/0000-0002-0496-9148
}

Received: 03.02.2020

Accepted: 15.06 .2020

Doi: $10.17522 /$ balikesirnef.683225

\begin{abstract}
This study investigated 46 preservice middle school mathematics teachers' solution strategies and determination and representation of proportional and nonproportional relationships in terms of problem contexts. In 2017 and 2018 fall semesters, the preservice teachers were given a paper-pencil test with two mathematical tasks. The preservice teachers' responses were analyzed using a content analysis method. Based on the analysis, semi-structured interviews were conducted with eight preservice teachers. The findings indicated that the preservice teachers' solution strategies and determination and representation of relationships were affected by the problem contexts. The preservice teachers were better at determining and representing inversely proportional relationship than directly proportional relationship, which was quite opposite of the findings usually cited in the literature. Determining and representing nonproportional relationship appeared to be the most challenging task for them. Problems that required in-depth examinations elicited the use of more sophisticated solution strategies and helped the preservice teachers to avoid applying rote computations.
\end{abstract}

Key words: mathematical representations, preservice teachers, problem context, proportional reasoning, proportional relationships.

Corresponding author: Muhammet ARICAN, Mathematics and Science Education Department. This study was supported by Kirsehir Ahi Evran University Scientific Research Projects Coordination Unit, Project Number: EGT.A4.18.014. This study was conducted during 2017 and 2018 academic years, and parts of it were presented as an oral presentation at the sixth International Eurasian Educational Research Congress (EJER) held between 19-22 June 2019 in Ankara. I would like to thank Dr. Wim Van Dooren and Dr. Lieven Verschaffel for their valuable feedback on earlier drafts of this paper, I also thank to TÜBİTAK- Directorate of Science Fellowships and Grant Programmes (BIDEB) for their support with providing me a research funding to stay in KU Leuven during which I was able to write this paper.

\section{Introduction}

Understanding ratios, proportions, and proportional relationships forms a very important part of school mathematics (Lamon, 2007; Lobato \& Ellis, 2010). However, these topics are 
regarded as the most challenging topics to learn in middle school (Arican, 2019; Izsák \& Jacobson, 2017; Lamon, 2007). In the literature, the ratio is defined as a multiplicative comparison of two quantities with the same or different units (Lobato \& Ellis, 2010). Whereas, a proportion is a mathematical expression showing the equality of two ratios (Fisher, 1988; Lobato \& Ellis, 2010). On the other hand, there are two types of proportional relationships: directly proportional and inversely proportional. Directly proportional relationships are modelled by the equation $y=k \cdot x$ (Lamon, 2007). In this equation, the variables $y$ and $x$ represent the quantities that are in a proportional relationship, and the amount $k$ represents the constant of proportionality. Hence, in a direct proportion, the ratios formed by the values of quantities are equal to a constant number. Whereas, the mathematical model for an inversely proportional relationship is $y \cdot x=k$. Therefore, the products of corresponding values are equal to a constant number in an inverse proportion. Understanding these constant ratio and constant product relationships is essential in distinguishing directly and inversely proportional relationships from each other as well as from nonproportional relationships.

Proportional reasoning is defined as "identifying, representing, analyzing, explaining, and providing evidence for proportional relationships" (Lamon, 2007, p. 647). Since identifying proportional relationships involve understanding multiplicative relationships between quantities compared, proportional reasoning has been regarded as a special form of multiplicative reasoning (Lesh, Post, \& Behr, 1988). Proportional reasoning is an important concept in understanding many situations in science and daily life (Cramer \& Post, 1993) and has a key role in the development of students' school arithmetic and higher mathematics (Kilpatrick, Swafford, \& Findell, 2001; National Council of Teachers of Mathematics [NCTM], 2000). Furthermore, proportional reasoning requires the determination of proportional relationships between quantities and representation of these relationships using mathematical models such as tables, graphs, equations, diagrams, and verbal descriptions (Common Core State Standards Initiative [CCSSI], 2010).

Students' and preservice teachers' (PSTs) difficulties with solving proportion problems and determining and representing proportional relationships have been reported by many studies (e.g., Arican, 2019; Fisher, 1988; Izsák \& Jacobson, 2017; Johnson, 2017; Lim, 2009; Modestou \& Gagatsis, 2007). In recent years, some researchers (e.g., Degrande, Van Hoof, Verschaffel, \& Van Dooren, 2017; Fernández, Llinares, Modestou, \& Gagatsis, 2010; Kaput \& West, 1994; Van Dooren, De Bock, \& Verschaffel, 2010) examined students' difficulties 
with proportional reasoning in terms of problem contexts. These researchers reported the effects of problem context on students' strategy choices, mathematical competences, and preferences for additive or multiplicative reasoning. However, there is not enough information in the literature on the effects of problem contexts on PSTs' solution strategies and determination and representation of proportional and nonproportional relationships. Understanding PSTs' difficulties with determining and representing proportional and nonproportional relationships can help university educators to better prepare these PSTs for their future careers. Hence, the mathematical knowledge for teaching (MKT) framework (e.g., Ball, Thames, \& Phelps, 2008) was followed when designing this study. The MKT framework was followed because it is essential to understand the PSTs' mathematical knowledge that they need to perform their work as teachers of mathematics. The results obtained from this study can provide diagnostic feedback to the university educators about the PSTs' content knowledge needed for teaching the concepts of ratio, proportion, and proportional relationship concepts. Therefore, the purpose of this study is to conduct in-depth examination to understand how the contexts used in ratio and proportion problems affect PSTs' strategy choices and determination and representation of the given relationships. Using two mathematical tasks, which include real-world problems with varying contexts, this study investigates the following research questions:

1. How do contexts of ratio and proportion problems affect preservice middle school mathematics teachers' solution strategy choices?

2. How do contexts of ratio and proportion problems affect preservice middle school mathematics teachers' determination of proportional and nonproportional relationships?

3. How do contexts of ratio and proportion problems affect preservice middle school mathematics teachers' representation of proportional and nonproportional relationships?

4. What difficulties do preservice middle school mathematics teachers encounter when solving ratio and proportion problems and determining and representing proportional and nonproportional relationships?

\section{Background}

In terms of determining proportional and nonproportional relationships in the given problems, researchers (e.g., Arican, 2019; Izsák \& Jacobson, 2017; Johnson, 2017; Lim, 
2009) stated PSTs' and in-service teachers' confusions between directly and inversely proportional relationships as well as between proportional and nonproportional relationships (e.g., relationships in the form of $\mathrm{y}=\mathrm{kx}+\mathrm{b}$, in which $\mathrm{x}$ and $\mathrm{y}$ are quantities compared and $\mathrm{k}$ and $b$ are numbers that are not zero). Arican (2019) discussed the PSTs' over attention to the qualitative relationships (i.e., simultaneous increases and/or decreases of quantities) and constancy of the rate of change when determining proportional and nonproportional relationships as two of the main challenges for determining these relationships. Although determining inversely proportional relationships expected to be more challenging than determining directly proportional relationships (e.g., Riley, 2010), there are quite inverse cases. For instance, in a study conducted with 40 PSTs, Arican (2019) reported that $50 \%$ and $15 \%$ of the PSTs determined the inversely and directly proportional relationships presented in a Gear task, respectively. Similarly, while $70 \%$ of the PSTs were able to solve the inverse proportion problem, only $42.5 \%$ of them were able to solve the direct proportion problem. In addition, Lim (2009) reported that the PSTs had more difficulty in determining nonproportional relationships than directly and inversely proportional relationships.

Regarding PSTs' representation of proportional and nonproportional relationships, Arican (2019) reported that $15 \%$ of the PSTs were able to draw directly proportional graphs. On the other hand, only $5 \%$ of these PSTs were able to draw inversely proportional graphs. Arican (2019) observed the PSTs' hesitations to start drawing their directly proportional graphs from the origin and tendencies to represent inversely proportional relationships with linear decreasing graphs with negative slopes. Similarly, Lo (2004) noted the PSTs' difficulties with drawing appropriate pictures to explain the meaning behind their solutions to a missing-value direct proportion problem. Moreover, students' and PSTs' overreliance on using rote computations and rules while solving proportion problems is also noted by researchers (e.g., Fisher, 1988; Harel \& Behr, 1995; Orrill \& Brown, 2012). Although these rules can be effective in terms of obtaining correct answers, students use them with little understanding of the multiplicative relationships presented (Arican, 2018; Izsák \& Jacobson, 2017; Kaput \& West, 1994).

As stated above, the effect of number size, problem type, and context on students' strategy choices, mathematical competence, and preference for additive or multiplicative reasoning has been also reported in the literature (e.g., Fernández, Llinares, Modestou, \& Gagatsis, 2010; Degrande et al., 2017; Kaput \& West, 1994). For instance, conducting a study with 138 sixth-grade students, Kaput and West (1994) found that the following features of 
proportion problems made them easier to answer: numerical features (e.g. using reduced form of ratios and familiar multiple) and semantic features (e.g., using for every/each statement and familiar rates). Conversely, the following features of problems made them difficult to answer: numerical features (e.g., non-integer ratios and small differences between the values of quantities) and semantic features (e.g., using ambiguous groups). On the other hand, Fernández et al., (2010) investigated the effect of context in terms of primary and secondary students' choices of strategies. They reported that when the quantities involved an integer relationship (i.e., integer ratio), students used more of ratio strategies. On the contrary, they used more of informal strategies such as build-up strategies more often when the quantities involved a non-integer relationship. Finally, Degrande et al. (2017) reported that children in upper primary education associated a comparing growths context with an additive model and suggested that students may associate contexts that involve time and distance with a multiplicative model. Thus, this current study contributes to the literature by investigating the effect of problem contexts on the PSTs' determination and representation of proportional and nonproportional relationships.

\section{Methods}

\section{Overall Research Design}

The purpose of this study was to provide an in-depth investigation of the effect of problem contexts on the PSTs' determination and representation of proportional and nonproportional relationships. An explanatory research design model is followed when developing this study because it helps researchers in understanding some phenomena more efficiently and allows both quantitative and qualitative methods when analyzing the data (Fraenkel \& Wallen, 2006).

\section{Participants and Recruitment Procedure}

During the fall semester of 2017, 26 PSTs (23 females and 3 males), who enrolled in the middle school mathematics program of a Turkish university, participated in the study. The PSTs were in their last year (i.e., fourth year) of the program and attending to a course on mathematical modelling. During the fall semester of 2018, the study was repeated with 20 PSTs (13 females and 7 males), who also attended to the same course, to have a convenient sample size. Except three PSTs, who were in the third year of the program, the remaining PSTs were in their last year of the program. I taught the course in both semesters, and all the 
PSTs who took the course participated in the study. Before their participation in the study, the PSTs in both groups did not have any university level instruction on proportional and nonproportional relationships. Hence, they solved the given problems using their previous knowledge that they usually received in middle and high school. In Turkey, the instruction on ratio and proportion concepts, which are provided in middle and high school, usually focuses on rule memorization and rote computations. Hence, students learn these concepts from a traditional perspective that emphasizes cross-multiplication and across-multiplication strategies when solving proportion problems. These PSTs were purposefully recruited because they were expected to teach ratio, proportion, and proportional relationship concepts immediately after graduation. Thus, a purposive sampling technique (e.g., Patton, 2005) was followed when recruiting these PSTs.

\section{Data Collection and Analysis}

The PSTs were provided with a paper-pencil test that included two mathematical tasks (Bicycle and Candle tasks). The PSTs were given 50 minutes to complete this test. I developed the Bicycle task myself and adapted the Candle task from Lim (2009). I decided to use these two tasks because both of them included real-life contexts and were appropriate for studying the PSTs' ability to determine and represent proportional and nonproportional relationships. In the adaptation of the Candle task, without changing the original context, I replaced numbers and letters provided by Lim (2009) with new numbers and letters. Since Lim (2009) designed this problem for PSTs, the problem was a valid and reliable source for adaptation.

I followed Hsieh and Shannon's (2005) conventional content analysis method when analyzing the PSTs' responses to these two tasks. In order to conduct this content analysis, I generated an Excel file and recorded summaries of each PST's responses in this file. I considered my research questions and related literature on PSTs' solution strategies (e.g., Fisher, 1988; Arican, 2018) and representations (e.g., Arican, 2019; Johnson, 2017; Lo, 2004) when generating these summaries. The summaries included information about the correctness of solutions and relationships identified, appropriateness of representations provided, relevance of mathematical interpretations, and strategies used in solving these problems. Using these summaries, I generated tables that gathered findings for each research question. In these tables, the findings were reported using descriptive statistics (i.e., frequencies and percentages) and supported by the pictures of the PSTs' written responses. Based on the 
summaries and tables, I selected eight PSTs (5 females and 3 males) and conducted brief individual semi-structured interviews with them to understand their reasoning in details. In my selection of these eight PSTs, I paid attention to obtain a sample who had varying achievements in solving the given problems. Hence, I coded the PSTs' answers as correct, partially correct, wrong, and no answer. Table 1 presents eight PSTs' responses to the Bicycle and Candle tasks. To maintain confidentiality, the PSTs' real names were replaced with pseudonyms. Each individual interviews were conducted in a single meeting and took between 30 to 60 minutes. During the interviews, the PSTs worked on their responses that they provided to the paper-pencil test, and I asked questions to them about their solutions and representations. I watched all collected interview videos and transcribed verbatim the necessary parts that I found important to discuss in the manuscript.

Table 1 Selected Eight Preservice Teachers' Responses to the Problems

\begin{tabular}{lllllllllll}
\hline \multicolumn{3}{c}{ Bicycle } & \multicolumn{1}{c}{ Candle } \\
& (a) & (b) & (c) & (d) & (e) & (f) & (a) & (b) & (c) & (d) \\
\hline Beril & C & W & C & C & NA & NA & C & C & C & NA \\
Zehra & C & W & C & NA & PC & NA & C & PC & W & NA \\
Mehmet & C & W & C & C & C & NA & C & C & C & C \\
Onur & C & W & W & W & C & C & C & C & W & W \\
Melisa & C & W & C & W & C & W & C & C & W & W \\
Mine & C & W & W & W & C & NA & C & C & W & NA \\
Hakan & C & C & C & C & C & PC & C & C & C & C \\
Merve & C & W & W & W & C & W & C & C & W & W \\
\hline Note. C: Correct; PC: Partially Correct; W: Wrong; and NA: No Answer. & &
\end{tabular}

\section{Mathematical Tasks}

As stated above, two mathematical tasks were used in this study (Table 2). The Bicycle tasks was suitable for examining the PSTs' reasoning on the direct and inverse proportions. In this task, the PSTs were told that two friends, Akin and Ayse, travelled a certain distance using their bicycles that had $30 \mathrm{~cm}$ and $20 \mathrm{~cm}$ wheel radius, respectively. Moreover, it was told that Akin and Ayse cycled their pedals at the same pace, and both bicycles had the same size pedal and rear wheel gears with $5 \mathrm{~cm}$ and $2 \mathrm{~cm}$ radius, respectively. In Bicycle (a), the PSTs had to calculate the number of pedaling that Ayse needed for completing the distance they travel given that Akin completed the same distance by pedaling his bicycle 200 times. The pedal gear and the gear on rear wheel were intertwined, so that they rotated together. 
Hence, there was an inversely proportional relationship between the size of gears and number of rotations that they made. There was also an inversely proportional relationship between the size of wheels and number of pedaling required for completing the distance.

Table 2 Problem Descriptions of the Mathematical Tasks

Task Problem Descriptions
(a) Cycling at the same pace, Akin completed the distance they travelled by pedaling his bicycle 200
times. How many times does Ayse need to pedal her bicycle to complete the same distance?
(b) Calculate the distance that they travelled.
(c) If Akin completed the distance in 16 minutes, please calculate how many minutes are needed by
Ayse to complete the same distance.

Bicycle (d) If pedal gear has 30 notches, how many notches are there around the gear located on the rear wheel?

(e) Please determine the relationship, if any, between the sizes of wheels and number of pedaling made for traveling the distance. Represent this relationship with an appropriate mathematical model.

(f) Please determine the relationship, if any, between the sizes of pedal and rear wheel gears and number of notches around them. Represent this relationship with an appropriate mathematical model.

(a) A candle burns at a constant rate. It is known that $15 \mathrm{~mm}$ of this candle was burn in 12 minutes, please calculate how much part of it burns in 20 minutes.

(b) If $n \mathrm{~mm}$ long part of this candle burns in $t$ minutes, please determine the relationship between $n$ Candle and $t$ and represent this relationship with an appropriate mathematical model.

(c) B and $\mathrm{C}$ are two identical candles burning at the same constant rate but they are lit at different times. When $16 \mathrm{~mm}$ of the candle $\mathrm{B}$ burns, $10 \mathrm{~mm}$ of the candle $\mathrm{C}$ burns. Please calculate how much part of the candle $\mathrm{C}$ burns when $24 \mathrm{~mm}$ of the candle B burns.

(d) Knowing that when $\mathrm{X} \mathrm{mm}$ of the candle B burns, Y mm of the candle $\mathrm{C}$ burns. Please determine the relationship, if any, between $\mathrm{X}$ and $\mathrm{Y}$ and represent this relationship with an appropriate mathematical model.

In Bicycle (b), the PSTs were asked to calculate the distance Akin and Ayse travelled. The distance could be presented by the equation, distance $=$ the number of rear wheel rotations * rear wheel circumference, in which the circumference was equal to the distance travelled in one rotation of a wheel. The distance equation necessitated a directly proportional relationship between the distance and number of rotations and between the distance and circumference. Similarly, there was an inversely proportional relationship between number of rotations and circumference. Therefore, recognizing an inversely proportional relationship between the size of a gear and number of rotations, a PST should calculate that Akin's rear 
gear made 500 rotations. This PST should understand that Akin's rear wheel also rotates 500 times because rear wheel completes the same number of revolutions as rear gear. Hence, the PST should calculate the distance Akin travelled using X $(\mathrm{cm})=500$ (rotations) $* 60 \pi$ (cm per rotation) formula. Considering the equity of distances Akin and Ayse travelled, the same PST should calculate the number of rotations on Ayse's rear gear as 750. Finally, using this information, the PST should calculate the number of rotations on her pedal as 300.

In Bicycle (c), the PSTs had to examine the directly proportional relationship between the number of pedaling and time needed for completing the distance in which the ratio of number of pedaling and number of minutes was equal to a constant (i.e., 25 rotations per 2 minutes). The same problem could be also solved recognizing the inversely proportional relationship between the radius of a wheel and time (i.e., $30 \mathrm{~cm} * 16$ minutes $=20 \mathrm{~cm} * 24$ minutes). In Bicycle (d), the PSTs had to investigate a directly proportional relationship between the sizes of gears and number of notches around them (i.e., 6 notches per $1 \mathrm{~cm}$ ). Bicycle (e) and (f) were about representing the directly and inversely proportional relationships described in here.

In Candle (a) and (b), the PSTs examined a directly proportional relationship between the height of burned part of a candle and time required for burning this part (i.e., $5 \mathrm{~mm}$ per 4 minutes). In Candle (c), the PSTs were given two identical candles, B and C, which were burning at the same constant rate but lit at different times. Next, they investigated the relationship between the heights of burning parts of candles. There was an additive relationship between the heights of burning parts (i.e., $16 \mathrm{~mm}-10 \mathrm{~mm}$ was equal to a constant) because two candles had the same constant burning rate but they were lit at different times.

\section{Results}

In this section, the PSTs' responses to the paper-pencil test and findings obtained from the semi-structured interviews are presented.

\section{The Preservice Teachers' Responses to the Paper-Pencil Test}

The PSTs' solutions to the paper-pencil test are classified as either correct, incorrect, incomplete, or no answer (Table 3). Table 3 shows that the PSTs were better at solving problems in Candle (a) and Bicycle (a). The PSTs obtained the lowest correct rate on the 
problem in Bicycle (b). Moreover, the PSTs' were better at answering the inverse proportion problem in Bicycle (c) than the direct proportion problem in Bicycle (d).

Table 3 The Distribution of the Preservice Teachers' Solutions

\begin{tabular}{llccccc}
\hline Problem & & $\begin{array}{c}\text { Correct } \\
\text { Solutions }\end{array}$ & $\begin{array}{c}\text { Incorrect } \\
\text { Solutions }\end{array}$ & $\begin{array}{c}\text { Incomplete } \\
\text { Solutions }\end{array}$ & $\begin{array}{c}\text { No } \\
\text { Answer }\end{array}$ & $\%$ \\
\hline \multirow{3}{*}{ Bicycle } & (a) & 36 & 4 & 4 & 2 & 78.3 \\
& (b) & 13 & 31 & 0 & 2 & 28.3 \\
& (c) & 27 & 14 & 0 & 5 & 58.7 \\
& (d) & 24 & 15 & 1 & 6 & 52.2 \\
Candle & (a) & 44 & 1 & 1 & 0 & 95.7 \\
& (c) & 22 & 22 & 1 & 1 & 47.8 \\
\hline
\end{tabular}

Regarding with the PSTs' solution strategies, in Bicycle (a), 24 PSTs used a distance formula, and 11 PSTs used an across-multiplication strategy. In Bicycle (b), the PSTs who calculated distance in terms of number of pedaling appeared to not recognize that the number of rotations on wheels was determined by the rotations made by the rear gear. Hence, 22 PSTs mistakenly calculated the distance in terms of number of pedaling (Figure 1), $X(\mathrm{~cm})=200$ (rotations) $* 60 \pi(\mathrm{cm}$ per rotation) and $\mathrm{X}=300$ (rotations) $* 40 \pi$ (cm per rotation), which must be either $\mathrm{X}=500$ (rotations) $* 60 \pi(\mathrm{cm}$ per rotation) or $\mathrm{X}(\mathrm{cm})=750$ (rotations) $* 40 \pi$ (cm per rotation). In Figure 2, the PST was able to calculate the correct number of pedaling on Ayse's bicycle; however, she incorrectly calculated the distance using the pedal rotations.

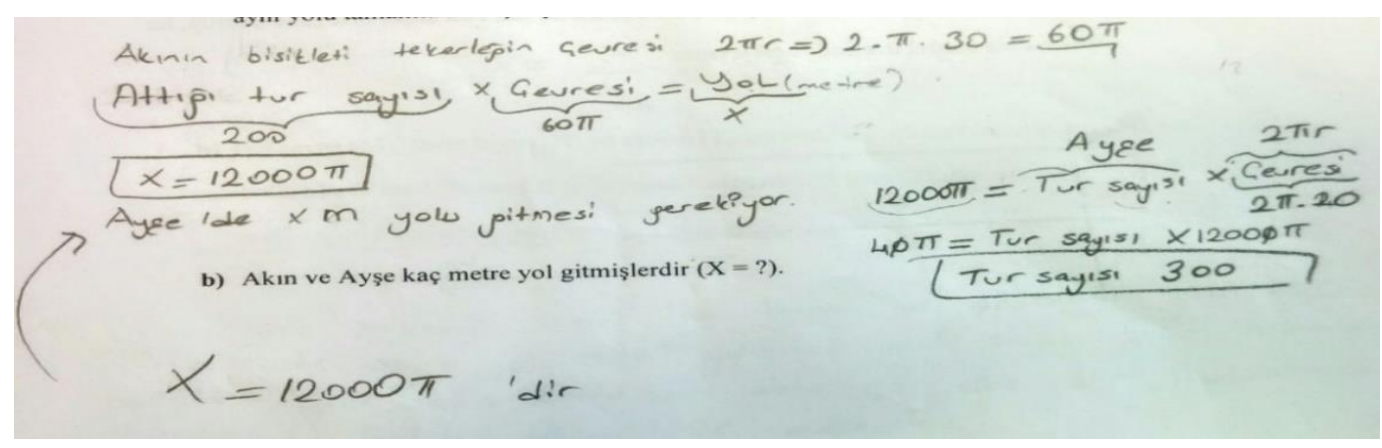

Figure 3 A PST's responses to the problems in Bicycle (a) and (b)

In Bicycle (c), Bicycle (d), and Candle (a), the PSTs mostly relied on the crossmultiplication and across-multiplication strategies. The PSTs used different variations of these two strategies in solving problems. Furthermore, the PSTs' responses suggested their 
difficulties with distinguishing directly and inversely proportional relationships from each other as well as distinguishing from nonproportional relationships. For instance, In Bicycle (c), six PSTs solved the problem incorrectly assuming a directly proportional relationship between time and wheel size. Moreover, three PSTs provided wrong answers assuming an inversely proportional relationship between time and number of pedaling. Similarly, in Bicycle (d), 10 PSTs calculated the number of notches around the rear gear as 75 notches, which should be 12 notches, assuming an inversely proportional relationship between the sizes of gears and number of notches around them. On the other hand, in Candle (c), only 22 PSTs recognized the constant difference between the heights of burning parts in two candles (e.g., Figure 2a) in which 16 PSTs $(34.78 \%$ ) erroneously calculated the height of the burning parts as $15 \mathrm{~mm}$ (Figure $2 \mathrm{~b}$ ) assuming a directly proportional relationship.

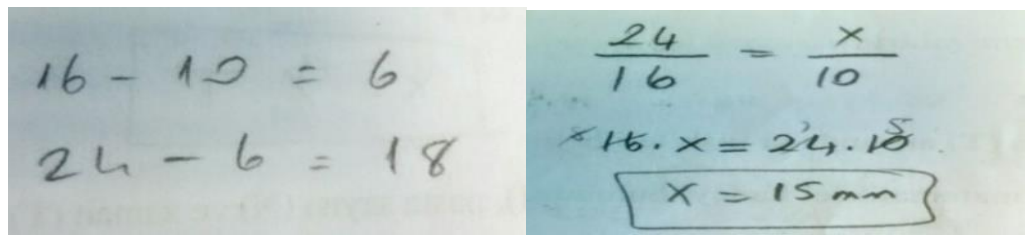

(a)

(b)

Figure 2 Two PSTs' responses to the problem in Candle (c)

When the PSTs' determination of the mathematical relationships are examined, Table 4 shows their weaknesses in identifying correct relationships. In the Bicycle task, more PSTs determined the inversely proportional relationship between the sizes of wheels and number of pedaling than the directly proportional relationship between the sizes of gears and number of notches. In the Candle task, although many PSTs determined the directly proportional relationship between the height of burned part of a candle and time required for burning this part, most of them had difficulty determining the additive relationship between the heights of burning parts in two candles.

Table 4 The Preservice Teachers' Determinations of the Mathematical Relationships

\begin{tabular}{|c|c|c|c|c|c|c|c|c|}
\hline & & DP & IP & $\mathrm{AD}$ & I-D & I-I & NA & Percent \\
\hline \multirow[t]{2}{*}{ Bicycle } & (e) & 1 & $* 27$ & 0 & 8 & 0 & 10 & 58.7 \\
\hline & (f) & $* 14$ & 4 & 0 & 0 & 5 & 23 & 30.4 \\
\hline \multirow[t]{2}{*}{ Candle } & (b) & $* 34$ & 2 & 2 & 0 & 7 & 1 & 73.4 \\
\hline & (d) & 15 & 1 & $* 9$ & 0 & 0 & 21 & 19.6 \\
\hline
\end{tabular}

Note. * indicates the correct answer; DP: Directly Proportional; IP: Inversely Proportional; AD: Additive; I-D: Increase-Decrease; I-I: Increase-Increase; and NA: No Answer. 
In Table 4, one PST described the inversely proportional relationship in Bicycle (e) as directly proportional, and eight PSTs described it as qualitatively (i.e., the radius increases and the number of rotations decreases) without recognizing proportionality. Moreover, four PSTs described the directly proportional relationship in Bicycle (f) as inversely proportional, and five PSTs described it as qualitatively (i.e., the radius increases and the number of notches increases). Furthermore, two PSTs stated the directly proportional relationship in Candle (b) as inversely proportional relationship, two PSTs described it as additively, and seven PSTs described it as qualitatively. Finally, 15 PSTs described the additive relationship in Candle (d) as directly proportional, and one PST described it as inversely proportional.

Considering qualitative relationships (i.e., I-D and I-I) as partially correct in Table 4, I examined the PSTs' determination of relationships within the bicycle context (Table 5) and between the bicycle and candle contexts (Table 6). Table 5 shows that 11 PSTs correctly identified both the inversely and directly proportional relationships. However, 10 PSTs who correctly identified the inversely proportional relationship did not provide a response for the directly proportional relationship. Moreover, nine PSTs did not provide a response for both relationships. Similarly, Table 6 shows that 11 PSTs correctly identified both relationships. On the other hand, 19 PSTs who identified the directly proportional relationship in the Candle task did not provide a response for the directly proportional relationship in the Bicycle task.

Table 5 The Preservice Teachers' Determination of the Directly and Inversely Proportional Relationships in the Bicycle Task

\begin{tabular}{llcccc}
\hline & \multicolumn{5}{c}{ Directly Proportional (Bicycle f) } \\
& C & PC & W & NA \\
\hline Inversely & PC & 11 & 3 & 3 & 10 \\
Proportional & W & 1 & 2 & 1 & 4 \\
$($ Bicycle e) & NA & 1 & 0 & 0 & 0 \\
\hline Note. C: Correct; PC: Partially Correct; W: Wrong; and NA: No Answer
\end{tabular}

Table 6 The Cross Analysis of the Bicycle Task and Candle

Task

\begin{tabular}{llllll}
\hline & \multicolumn{4}{c}{ Directly } & Proportional (Candle b) \\
C & PC & W & NA \\
\hline
\end{tabular}




\begin{tabular}{|c|c|c|c|c|c|}
\hline & $\mathrm{C}$ & 11 & 2 & 1 & 0 \\
\hline Directly & $\mathrm{PC}$ & 2 & 3 & 0 & 0 \\
\hline Proportional & $\mathrm{W}$ & 2 & 2 & 0 & 0 \\
\hline (Bicycle f) & NA & 19 & 0 & 3 & 1 \\
\hline
\end{tabular}

The PSTs' representations of the relationships could be classified under three main categories: formula, graph, and other type of representations (i.e., table, diagram, figure, etc.) (Table 7). In Table 7, the total number exceeds 46 since some PSTs provided more than one representation. In their representations of the relationships, the PSTs usually provided direct and inverse proportion graphs and their formulas (Figure 3). Partially correct representations suggested some understanding of the PSTs, but the graph or the formula was not correct or complete. Many of the PSTs had difficulty representing the nonproportional and directly proportional relationships presented in Candle (d) and Bicycle (f), respectively. In Candle (d), 15 PSTs incorrectly determined the additive relationship as directly proportional. Hence, these PSTs tended to represent this additive relationship by providing either a direct proportion formula and/or a graph of it. On the other hand, in Bicycle (f), 24 PSTs did not provide a representation of the directly proportional relationship. Hence, high no answer rate in that problem suggested issues with the PSTs' understanding of this relationship.

Table 7 The Distribution of the Preservice Teachers' Mathematical

\section{Representations}

\begin{tabular}{lccccccccccc}
\hline Problem & & \multicolumn{3}{c}{ Formula } & \multicolumn{3}{c}{ Graph } & & Other & NA \\
& & C & PC & W & C & PC & W & C & PC & W & \\
\hline Bicycle & (e) & 12 & 7 & 2 & 1 & 11 & 6 & 1 & 0 & 1 & 14 \\
& (f) & 5 & 4 & 5 & 1 & 7 & 2 & 2 & 1 & 2 & 24 \\
Candle & (b) & 10 & 19 & 5 & 5 & 17 & 3 & 1 & 2 & 0 & 2 \\
& (d) & 8 & 4 & 16 & 0 & 1 & 9 & 0 & 0 & 6 & 11 \\
& & & & & & & & & & &
\end{tabular}

Note. C: Correct; PC: Partially Correct; W: Wrong; and NA: No Answer 


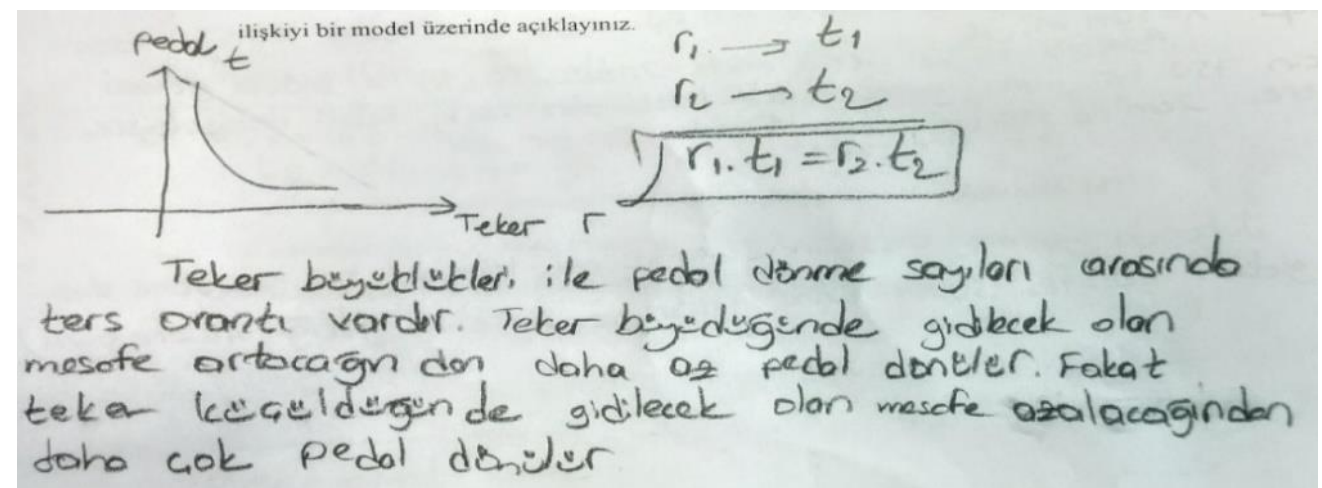

Figure 3 A PST's correct representations of the inversely proportional relationship in Bicycle (e)

\section{Semi-Structured Interviews}

To understand the PSTs' reasoning in detail, I conducted brief individual semistructured interviews with eight PSTs. In the following pages, I present only Hakan's and Merve's responses to the interview questions in details. These two PSTs' responses were provided because Hakan and Merve were the most successful and weakest of the eight PSTs, respectively (see Table 1). In the transcripts, pauses were shown with ellipses and actions were described within square brackets, and figures show the PSTs' responses to the paperpencil test.

Hakan, who was in his third year of the program, was the only student who provided correct response for Bicycle (b). Similarly, only Hakan and another PST provided correct responses for Candle (d). In his response to the distance travelled by Akin and Ayse, Hakan calculated that rear wheel rotated 10 times for every 4 rotations of the pedal (Figure 4). When I asked him about how he obtained 10 and 4 rotations, he responded as follows:

Hakan $(\mathrm{H})$ : Because as the radius decreases the number of rotations increases.

Interviewer (INT): How did you obtain this information?

$\mathrm{H}$ : Because my previous knowledge on physics. I have worked on the topic of gears in physics, so I used this information. I equated $10 \pi$ and $4 \pi$ at $40 \pi$. I said $4 \pi$ should be 40 , so it makes 10 rotations. Next, I said $10 \pi$ should rotate four times for being equal to $40 \pi$.

INT: How did you calculate 500 rotations?

$\mathrm{H}$ : To equate four rotations to 200 rotations, I said we need to multiply by 50 . Hence, multiplying 10 by 50 , I got 500 rotations.

INT: Then from here, you calculated $30000 \pi$. How did you calculate that?

$\mathrm{H}$ : It was the distance $\mathrm{X}$....using $2 \pi \mathrm{r}$ and taking radius as 30 , I calculated the circumference of the wheel as $60 \pi$.

INT: What did $60 \pi$ give you? 
$\mathrm{H}$ : The distance covered in one rotation. Next, I said if it covers $60 \pi$ in one rotation, for a total of 500 rotations on the rear wheel...one rotation becomes 500 rotations, so I said we need to multiply 60 by 500 . When I multiplied, I calculated X as 30000 .

Figure 4 and the exchanges above show that Hakan's previous knowledge on gears, which he studied in physics classes, facilitated him in calculating the distance covered by each bicycle. Hence, using his experience on gears, Hakan was able to determine the inverse relationship between the radius and number of rotations which he stated by saying "as the radius decreases the number of rotations increases." His responses above show that he was reasoning multiplicatively and knew that the circumference of the wheel was equal to the distance covered in one rotation.

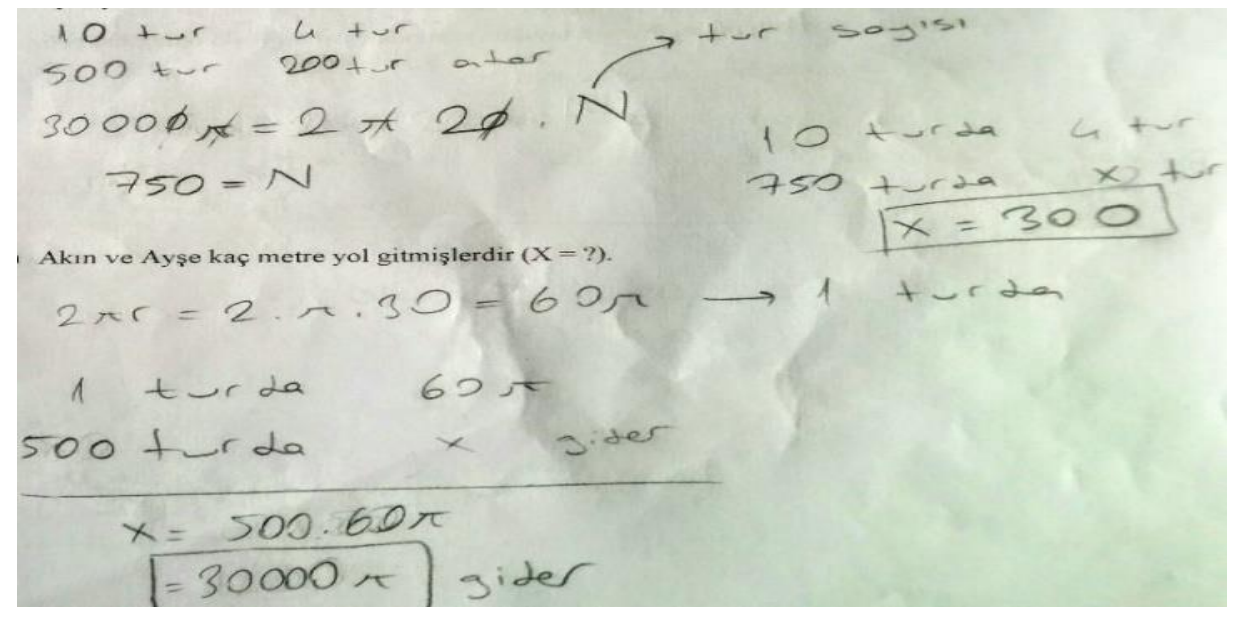

Figure 4 Hakan's responses to the problems in Bicycle (a) and (b)

In Bicycle (e), Hakan wrote that "If we take the distance as constant, then when the size of a wheel increases, the number of rotations on pedal decreases in a certain ratio." Next, taking an arbitrary measure for the distance (i.e., $4800 \pi$ ), he represented the relationship between the radius and number of rotations by $X=2400 /$ radius (Figure 5). However, he did not provide a graph of this inversely proportional relationship. During the interview, I asked him about what kind of a relationship there was between the radius and number of rotations. $\mathrm{He}$ responded as follows:

H: I said inverse proportion, but I did not write it.

INT: How did you know there was an inverse proportion?

$\mathrm{H}$ : I think, my radius is decreasing and rotations on the pedal increases [pointing out his calculations]. Normally, in the inverse proportion, we get the same result when we multiply, so it is an inverse proportion.

INT: What do you mean by multiply? 
$\mathrm{H}$ : We always get 2400 when we multiply the number of rotations on pedal and radius of the wheel. Since the distance is constant, the multiplication of the number of rotations on pedal and wheel radius must be equal.

INT: Did you notice this equity during the test or recognized it now?

$\mathrm{H}$ : I noticed it when I was taking the test and considered this equity when I obtaining my formula which already shows the inverse proportion.

In his determination of the inversely proportional relationship, Hakan both attended to the simultaneous increases and decreases which he stated by saying "my radius is decreasing and rotations on the pedal increases" and the constant product relationship between quantities multiplied which he also stated by saying "Normally, in the inverse proportion, we get the same result when we multiply." Thus, Hakan's responses above suggested his understanding of the inversely proportional relationship between the radius and number of rotations.

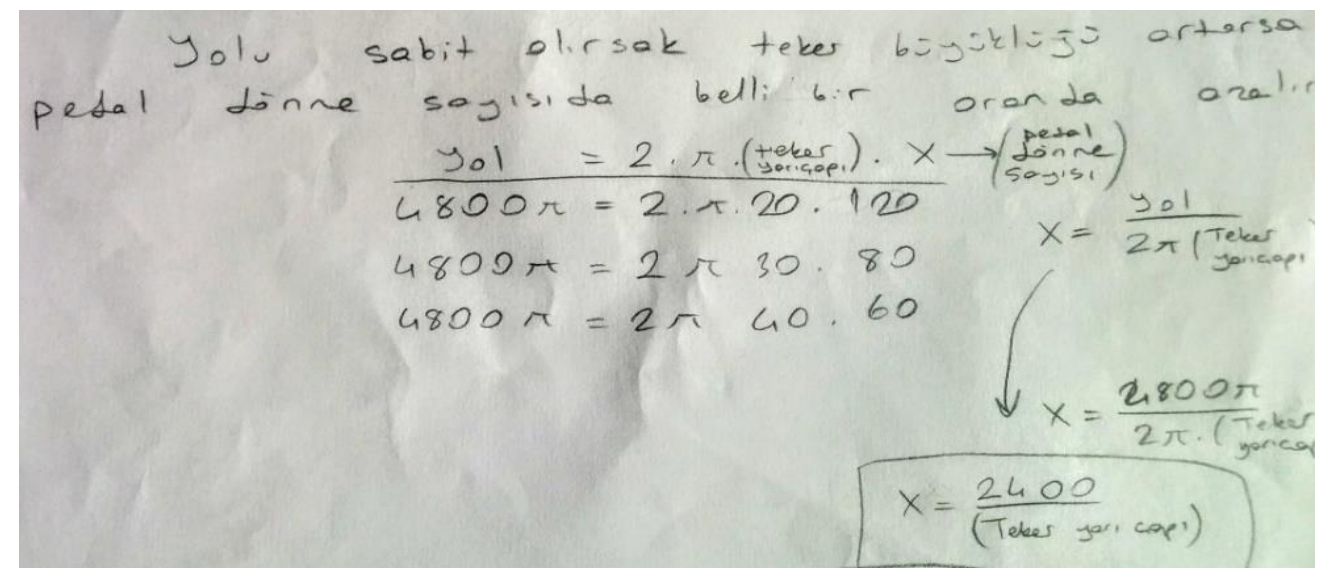

Figure 5 Hakan's representation of the inversely proportional relationship in Bicycle (e)

In Bicycle (f), Hakan described the relationship between the number of notches and radius by also attending to the simultaneous increases and decreases, which he stated by writing "When the pedal radius increases, the number of notches increases" and "When the pedal radius decreases, the number of notches decreases." However, he obtained an incorrect formula, Distance=Circumference/(number of notches), and did not provide a graph of this relationship. During the interview, he recognized that his formula was not correct but could not obtain the correct formula. Similar to the previous problem, I asked if there was a name of the relationship between the number of notches and radius which he described earlier. He responded as follows:

$\mathrm{H}$ : I thought it as the direct proportion.

INT: Why did you think that way? 
$\mathrm{H}$ : As the radius increases, the circumference also increases and so more notches can be placed around it. If the radius decreases, less notches will be around it. Hence, I thought it as the direct proportion.

INT: In the previous question, you said there was an inverse proportion and stated that their products were constant. Do you think there is or there should be a similar situation in the direct proportion?

$\mathrm{H}$ : It should be...their division must be equal to a constant.... if we write it, both $10 \pi$ divided by 30 and $4 \pi$ divided by 12 equals to $\pi$ over 3 [He wrote $10 \pi / 30=\pi / 3$ and $4 \pi / 12=\pi / 3]$.

INT: Did you notice that now or noticed it during the test?

H: I noticed it right now.

In Bicycle (e), Hakan's attention to the constancy of the products appeared to facilitate him in obtaining the formula. On the other hand, although he recognized the constancy of ratios during the interview, he did not attempt to correct his incorrect formula.

Hakan recognized the additive relationship in Candle (d) and represented this relationship with $\mathrm{X}-\mathrm{Y}=\mathrm{k}$ in which he wrote that $\mathrm{k}$ was showing the difference between the lengths of burnings parts in two candles. During the interview, Hakan said the relationship between the lengths of burnings parts was not proportional but there was a constant difference between the lengths of burning parts. Therefore, his understanding of this additive relationship suggested that he was able to distinguish proportional and nonproportional relationships.

In her responses to the problems, Merve did not often state units, so I showed them between square brackets. Merve was able to calculate the number of rotations in Ayse's bicycle using an across-multiplication strategy (i.e., $0.6 \pi * 200$ rotations $=0.4 \pi * \mathrm{X}$ rotations). Although an across-multiplication strategy assumes an inversely proportional relationship between quantities compared, during the interview Merve stated the relationship between the circumference of a wheel and number of rotations as directly proportional. When I reminded her that the across-multiplication strategy necessitates an inversely proportional relationship, she responded as follows:

Merve (M): I considered this as directly proportional because if it was inversely proportional, this wheel has smaller circumference [pointed at $0.4 \pi$ ] then it would go less distance. Hence, it should be directly proportional, so that it can go more distance.

Merve's response above suggested an inconsistency between her solution strategy and determination of the relationship. She decided the directly proportional relationship independently from her solution. She appeared to mix the directly proportional between the 
distance and circumference with the inversely proportional relationship between the circumference and number of rotations.

In Bicycle (b), Merve calculated the distance as $500 \pi$ meters $(X=[0.6 \pi$ meter $+0.4 \pi$ meter $] *$ [200 rotations +300 rotations $])$. During the interview, she stated that "I thought this [distance] as distance equals speed multiplied by time....next, I considered circumference as speed and rotations as time." Applying her formula one more time separately for both bicycles, she obtained $1200 \pi$ meter as her answer. Although her original and new responses were both incorrect, she became aware of the mistake that she had done in her original response. In Bicycle (c), modifying her initial distance formula, she wrote that " $\mathrm{X}=16$ [minutes] $* 200$ [rotations] $=\mathrm{t}$ [minutes] $* 300$ [rotations]" and calculated the answer as 32/3 minutes, which should be 24 minutes. During the interview, I asked Merve that thinking independent of her original response who completes the distance quicker Akin or Ayse. She responded as follows:

M: It seems like Akin completes the distance quicker, because he has longer circumference.

INT: So, you mean his bicycle has a wheel with longer circumference?

M: Yes. When he rotates one time, other one has to return more....So, I expect Akin to complete distance in less time than Ayse.

Next, I asked Merve to divide 32 by 3 and so reminded the inconsistency between her original answer and her thoughts above. She realized the inconsistency but could not calculate the correct answer using other solution strategies. Merve's overreliance on the distance formula obstructed her from obtaining a correct solution strategy.

Merve also obtained an incorrect answer for Bicycle (d). She multiplied 30 [notches] by $5[\mathrm{~cm}]$ and equated this to $2[\mathrm{~cm}]$ times a [notches]. Hence, she obtained an incorrect answer, 75 notches. When I asked Merve to explain her answer, she responded as follows:

M: I thought this as follows, there is an inverse proportion in here. If the radius is bigger than the number of notches....becomes more. I used this information. So, the product of the radius and number notches should be equal.

INT: Did you say more notches or less notches?

M: If the radius is bigger than there are more notches.

Merve's responses above again showed an inconsistency between her reasoning and solution. When reminded this inconsistency, she responded that "Now I think this as a direct proportion, but in this solution [pointed at 75 notches], I used an inverse proportion.” Next, I asked Merve how she understood that she used an inverse proportion in the original response. 
She said that "Because I multiplied them...if the radius was increased, this [pointed at the number of notches] should have decreased." Some exchanges later, she corrected her mistake and calculated the correct answer, 12 notches, by showing the equity of ratios (i.e., $2[\mathrm{~cm}] / 5$ $[\mathrm{cm}]=\mathrm{a}$ [notches] $/ 30$ [notches]). This finding also shows that how Merve calculated her solution independent from the problem context.

Merve is a good example for PSTs who correctly identified both the inversely and directly proportional relationships in Bicycle (e) and Candle (b), respectively but could not determine the directly proportional relationship in Bicycle (f), which she determined as inversely proportional. In Bicycle (e), Merve determined the relationship as inversely proportional, which she stated by writing "These [i.e., the number rotations and size of wheels] become inversely proportional" and showed the equality of products (i.e., 30 [cm]* 200 [rotations] $=30[\mathrm{~cm}] * 200$ [rotations]) (Figure 6a). However, using two pairs of values, she drew the inversely proportional graph as it was representing a linear decreasing relationship with a negative slope. During the interview, I asked Merve if she was given more pairs of numbers what her graph would look like, she generated new pairs and obtained the correct inversely proportional graph (Figure 6b). She was able to see that the line of the graph should not intersect with the axes, so decided this new graph was more appropriate than the original one. Later, I asked Merve why she originally drew the inversely proportional graph as linear and intersecting with the axes. She said that "This is how I learned inverse proportion in middle school. Teachers used to draw inverse proportion graph like this [pointed at the graph in Figure 6a]."

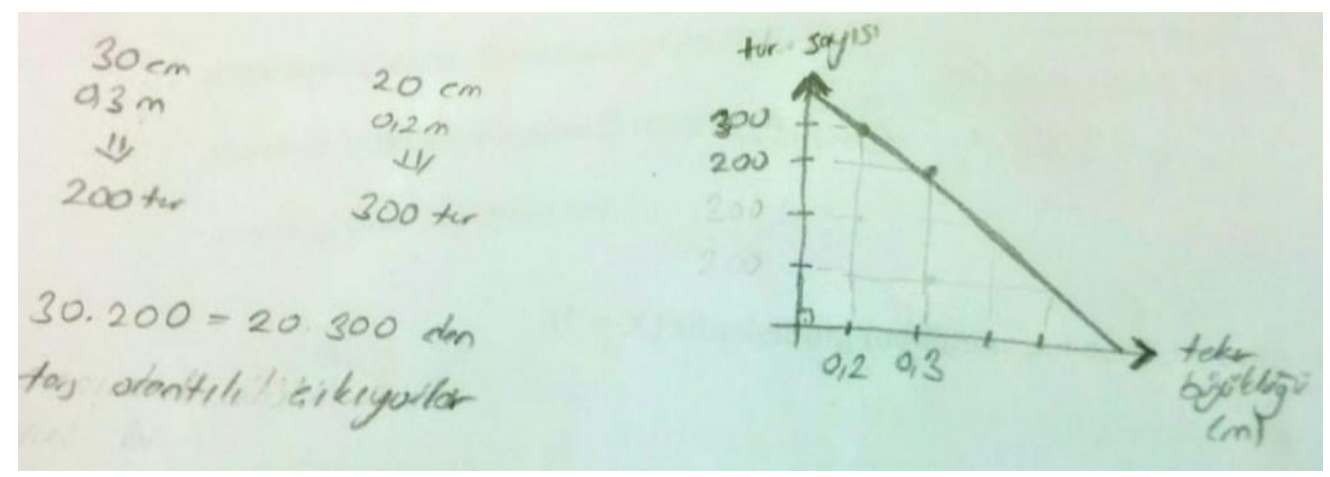

(a) 


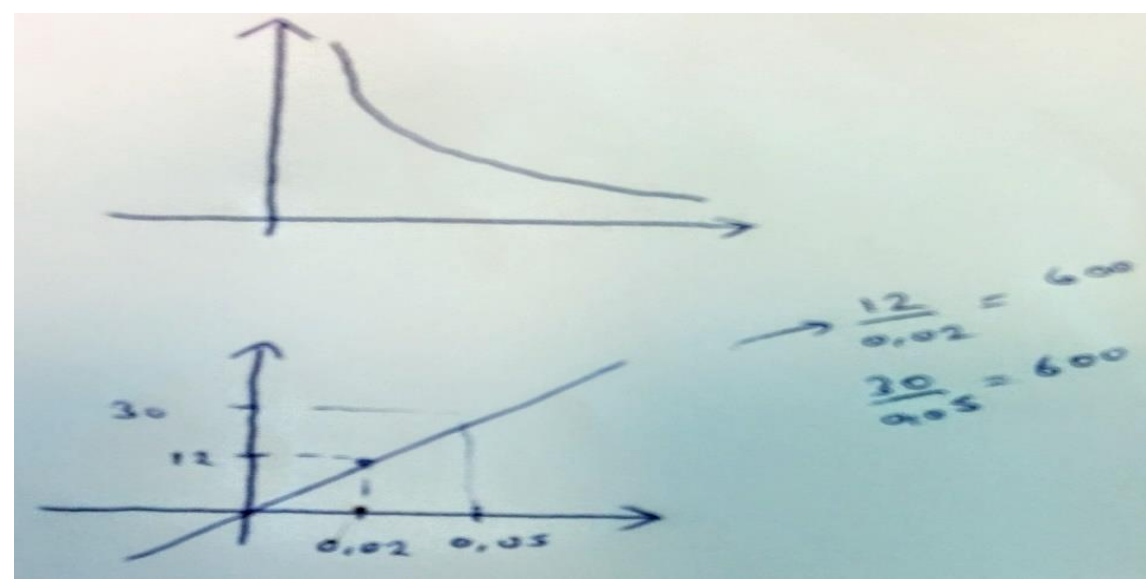

(b)

Figure 6 (a) Merve's incorrect representation in Bicycle (e); (b) Merve's correct representations in Bicycle (e) and Bicycle (f)

In Bicycle (f), assuming an inversely proportional relationship between that the radius and number of notches, Merve drew the incorrect linear graph again (Figure 7). In her response, she wrote that "Again there is an inverse proportion" and showed that the product of the radius and number of notches was equal in two gears, which she represented by the equation " 0.05 [meters] $\times 30$ [notches] $=0.02$ [meters] $\times 75$ [notches]. In this problem, Merve's mistake was a reflection of her incorrect answer (i.e., 75 notches) to Bicycle (d). During the interview, Merve initially thought that her graph in Figure 7 was correct. Later, I reminded her that she corrected 75 notches and found it to be 12 notches. Hence, using this new information, she was able to draw the correct graph (see Figure 6b). However, she still expected the products to be equal and responded as follows:

M: I corrected my graph but the product of these are not equal.

INT: What do you mean by these?

M: When I multiply 0.02 by 12 and 0.05 by 30, these two are not equal. Hence, these are not directly proportional.

INT: So, do you expect products to be equal in a directly proportional relationship?

M: Yes.

Merve's responses above indicated her confusion about the directly and inversely proportional relationships. She could not describe the relationship in this problem but stated that "It is neither directly proportional nor inversely proportional." 


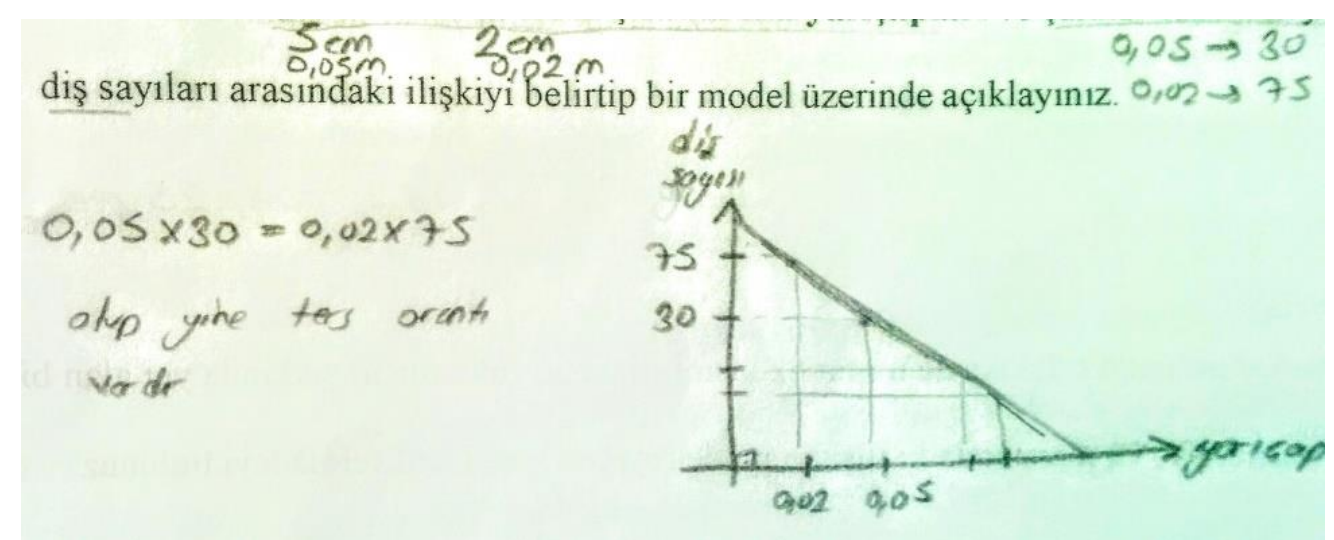

Figure 7 Merve's incorrect representation in Bicycle (f)

In Candle (a), Merve stated that there was a directly proportional relationship and using the cross-multiplication algorithm, she obtained the correct answer, $25 \mathrm{~mm}$. In Candle (b), she wrote that " $\mathrm{t}$ minutes and $\mathrm{n} \mathrm{mm}$ are directly proportional. When the time increases, the height of the burning part also increases." She also drew a directly proportional graph but did not use numbers instead used letters (Figure 8). During the interview, I asked Merve if she obtained a formula using $\mathrm{n}$ and $\mathrm{t}$ values, whether the product of these were equal for all pairs or not. She responded as follows:

M: Yes, the products of these will be equal...[she wrote $n 1 * t 1=n 2 * t 2$ ] because the slopes are all equal in this graph....[after some minutes] No this is not going to be like that. It should be $\mathrm{n} 1 / \mathrm{t} 1=\mathrm{n} 2 / \mathrm{t} 2$. One minute, this [pointed at the graph in Figure $6 \mathrm{~b}$ ] is also directly proportional.

INT: Why?

M: It is directly proportional because in fact I should have divided rather than multiplied. Then, this becomes correct.

INT: Why did you initially said the products are not equal for this?

M: That time I thought this as inversely proportional, but it is directly proportional.

Using the context of candles, Merve finally recognized her mistake in Bicycle (f) and showed the equity of ratios (see Figure 6b). Next, she stated that "Earlier, in this graph [pointed at the directly proportional graph in Figure 8], I said the slopes should be equal. It came to my mind using division from this slope idea." 


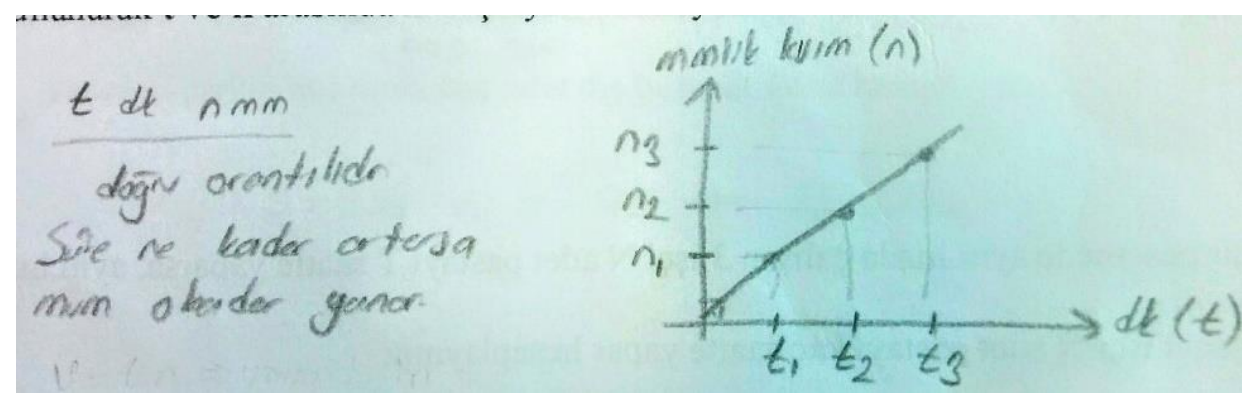

Figure 8 Merve's determination and representation of the directly proportional relationship in Candle (b)

In Candle (c), Merve stated that she used the Speed formula (i.e., $V=x / t$ ), which necessitated a directly proportional relationship, because the burning rates of two candles were the same. Using this formula, she incorrectly calculated the answer as $15 \mathrm{~mm}$. In Candle (d), Merve stated that there was a directly proportional relationship and represented it by showing the equality of two ratios (i.e., $\mathrm{X} / \mathrm{t} 1=\mathrm{Y} / \mathrm{t} 2$ ). During the interview, Merve did not recognize that there was an additive relationship between the heights of burning parts in two candles.

\section{Conclusion and Discussion}

In recent years, more attention has been given to identifying students' and PSTs' proportional reasoning and difficulties with this complex concept. Moreover, the influence of the problem contexts has been investigated in terms of student achievement. However, there is not enough research on the effects of problem contexts on PSTs' solution strategy choices and determination and representation of proportional and nonproportional relationships. Therefore, in this study, the effects of problem contexts on the PSTs' strategy choices and determination and representation of proportional and nonproportional relationships were investigated. In addition, the difficulties that the PSTs encountered when determining and representing proportional and nonproportional relationships were also examined in the light of problem contexts.

Regarding the first research question, the PSTs used a variety of solution strategies to answer problems. Although there were cognitively intriguing solutions, especially in Bicycle (a) and (b), many solutions relied on the cross-multiplication and across-multiplication strategies. In Bicycle (a) and (b), to calculate correct answers, most of the PSTs used a distance formula, which was very much similar to the one that they learned in middle and high school mathematics classes. Hence, in some extent, the context facilitated these PSTs in 
avoiding the cross-multiplication and across-multiplication strategies. In Bicycle (c) and (d) and in Candle (a), the majority of the PSTs relied on the cross-multiplication and acrossmultiplication strategies. In addition, in Candle (c), expecting a directly proportional relationship, 16 PSTs used the cross-multiplication strategy and obtained incorrect answers. The problems in Bicycle (c) and (d) and Candle (a) and (c) might have inclined the PSTs to apply the cross-multiplication and across-multiplication strategies because they could be solved easily using these two strategies and did not involve an in-depth examination as in Bicycle (a) and (b). However, as in Merve's case, some PSTs may automatically apply rules or formulas not necessarily thinking about problem contexts. Therefore, the findings suggest that using real-life problems with contexts that require in-depth explorations can help PSTs to avoid rote computations and can lead to the use of more cognitively intriguing strategies.

In terms of the second research question, in the Bicycle task, the PSTs were better at determining the inversely proportional relationship than the directly proportional relationship (see Table 5). This result is interesting because literature (e.g., Riley, 2010) usually reports the quite opposite of this finding. However, similar to this current study, using a gear context, which was similar in nature with the bicycle context, Arican (2019) also reported the PSTs' better performances in determining the inversely proportional relationship than determining the directly proportional relationship. The difference between the PSTs' success rates in determining the inversely and directly proportional relationships can be explained by the fact that most of these PSTs were quite familiar with the context of riding a bicycle. On the other hand, in their lives, they might not need to think about the relationship between the size of a gear and number of notches around it. Furthermore, comparing the directly proportional relationships in Bicycle (f) and Candle (b), more PSTs were able to determine this relationship in Candle (b) than Bicycle (f) (see Table 6). It appeared that the candle context was easier for the PSTs to comprehend than the bicycle context. The problems in the Bicycle task involved knowledge of physics, and the PSTs with this type of knowledge, such as Hakan, were better at solving bicycle problems. On the contrary, the PSTs were pretty much familiar with the context of candle because they either use candles in their homes or at least had a chance to observe the burning of a candle. Thus, the PSTs' familiarity with the problem contexts was the main factor in their successes in determining these two relationships.

Regarding with the third research question, the PSTs represented proportional and additive relationships either forming a formula or drawing a graph. There was a limited number of other types of representations (i.e., tables, diagrams, pictures, etc.). Considering 
wrong and no answer rates, the PSTs mostly had difficulty in providing representations for the additive and directly proportional relationships presented in Candle (d) and Bicycle (f), respectively. Therefore, their ability to provide representations was affected by difficulties that they faced with determining these two relationships. The PSTs also had difficulty with the representation of the inversely proportional relationship. For instance, Merve drew the inversely proportional graph as it was representing a linear decreasing relationship with a negative slope. During the interview, Merve stated that she learned this incorrect graph in middle school. Hence, in some extend, the PSTs' difficulties with representing proportional and nonproportional relationships can be linked to the inappropriate instruction that they received on these relationships. Providing PSTs with rich mathematical tasks and encouraging them for generating representations can deepen their proportional reasoning (Lo, 2004). Thus, it is necessary for mathematics educators to encourage PSTs to use multiple representations when teaching ratios, proportions, and proportional relationships. Encouraging PSTs to use representations in their solutions can help overcoming issues that they face with these concepts (Johnson, 2017).

In terms of the last research question, some PSTs had difficulty in determining relationships and distinguishing directly and inversely proportional relationships from each other and as well as from nonproportional relationships. This result confirms the findings obtained in previous studies (e.g., Arican, 2019; Cramer, Post, \& Currier, 1993; Izsák \& Jacobson, 2017; Lim, 2009). Moreover, high no answer rates for Bicycle (f) and Candle (d) suggested issues with the PSTs' understanding of the directly proportional and additive relationships presented in these two problems, respectively. I expected determining the additive relationship in Candle (d) to be challenging for the PSTs because they were not familiar with this type of context. However, I expected them to determine the directly proportional relationship in Bicycle (f), but many of them did not provide a response for this relationship. In Bicycle (d), 10 PSTs used an across-multiplication strategy expecting an inversely proportional relationship between the radius and number of notches. This finding suggests that the problem context (i.e., number of notches) might have directed them to an incorrect inference of an inversely proportional relationship.

As stated above, the findings of this study indicated issues with the PSTs' proportional reasoning. Since these PSTs will be teaching ratio, proportion, and proportional relationship concepts after graduation from university, mathematics education at the university level should involve courses that aim at developing PSTs' MKT on these concepts. Therefore, 
university educators should pay attention to research findings such as the ones presented in this study to provide appropriate instruction on these concepts.

\section{References}

Arican, M. (2018). Preservice middle and high school mathematics teachers' strategies when solving proportion problems. International Journal of Science and Mathematics Education, 16(2), 315-335.

Arican, M. (2019). Preservice mathematics teachers' understanding of and abilities to differentiate proportional relationships from nonproportional relationships. International Journal of Science and Mathematics Education, 17(7), 1423-1443.

Ball, D. L., Thames, M. H., \& Phelps, G. (2008). Content knowledge for teaching what makes it special? Journal of Teacher Education, 59(5), 389-407.

Cramer, K., \& Post, T. (1993). Making connections: A case for proportionality. Arithmetic Teacher, 60(6), 342-346.

Cramer, K., Post, T., \& Currier, S. (1993). Learning and teaching ratio and proportion: Research implications. In D. Owens (Ed.), Research ideas for the classroom: Middle grades mathematics (pp. 159-178). New York, NY: Macmillan.

Common Core State Standards Initiative (2010). The common core state standards for $\begin{array}{lll}\text { mathematics. } & \text { Washington, } & \text { Duthor. }\end{array}$ http://www.corestandards.org/assets/CCSSI_Math\%20Standards.pdf

Degrande, T., Van Hoof, J., Verschaffel, L., \& Van Dooren, W. (2017). Open word problems: Taking the additive or the multiplicative road?. ZDM, 50(1-2), 91-102. https://doi.org/10.1007/s11858-017-0900-6

Fernández, C., Llinares, S., Modestou, M., \& Gagatsis, A. (2010). Proportional reasoning: How task variables influence the development of students' strategies from primary to secondary school. Acta Didactica Universitatis Comenianae Mathematics, 10, 1-18. http://hdl.handle.net/10045/16588

Fisher, L. C. (1988). Strategies used by secondary mathematics teachers to solve proportion problems. Journal for Research in Mathematics Education, 19(2), 157-168. http://www.jstor.org/stable/749409

Fraenkel, J. R., \& Wallen, N. E. (2006). How to design and evaluate research in education (6th ed.). New York: NY, McGraw-Hill. 
Harel, G., \& Behr, M. (1995). Teachers' solutions for multiplicative problems. Hiroshima Journal of Mathematics Education, 3, 31-51.

Hsieh, H. F., \& Shannon, S. E. (2005). Three approaches to qualitative content analysis. Qualitative health research, 15(9), 1277-1288.

Izsák, A., \& Jacobson, E. (2017). Preservice teachers' reasoning about relationships that are and are not proportional: A knowledge-in-pieces account. Journal for Research in Mathematics $\quad$ Education, $\quad$ 300-339. https://doi.org/10.5951/jresematheduc.48.3.0300

Johnson, K. (2017). A study of pre-service teachers use of representations in their proportional reasoning. In Galindo, E., \& Newton, J., (Eds.), Proceedings of the 39th North American Chapter of the International Group for the Psychology of Mathematics Education conference (pp. 551-558). Indianapolis, IN. https://files.eric.ed.gov/fulltext/ED581310.pdf

Kaput, J. J., \& West, M. M. (1994). Missing-value proportional reasoning problems: Factors affecting informal reasoning patterns. In G. Harel \& J. Confrey (Eds.), The development of multiplicative reasoning in the learning of mathematics (pp. 235-287). Albany, NY: State University of New York Press.

Kilpatrick, J., Swafford, J., \& Findell, B. (2001). Adding it up: Helping children learn mathematics. Washington, DC: National Academy Press.

Lamon, S. (2007). Rational numbers and proportional reasoning: Toward a theoretical framework for research. In F. K. Lester, Jr. (Ed.), Second handbook of research on mathematics teaching and learning (Vol 1, pp. 629-667). Charlotte, NC: Information Age Publishing.

Lesh, R., Post, T., \& Behr, M. (1988). Proportional reasoning. In J. Hiebert \& M. Behr (Eds.), Number concepts and operations in the middle grades (pp. 93-118). Reston, VA: National Council of Teachers of Mathematics.

Lim, K. (2009). Burning the candle at just one end: Using nonproportional examples helps students determine when proportional strategies apply. Mathematics Teaching in the Middle School, 14(8), 492-500. 
Lo, J. J. (2004). Prospective elementary school teachers' solution strategies and reasoning for a missing value proportion task. In M. J. Høines \& A. B. Fuglestad (Eds.), Proceedings of the 28th International Group for the Psychology of Mathematics Education Conference (pp. 265-272). Bergen, Norway. http://emis.ams.org/proceedings/PME28/RR/RR207_Lo.pdf

Lobato, J., \& Ellis, A. (2010). Developing essential understanding of ratios, proportions, and proportional reasoning for teaching mathematics: Grades 6-8. National Council of Teachers of Mathematics. 1906 Association Drive, Reston, VA 20191-1502. https://eric.ed.gov/?id=ED511861

Modestou, M., \& Gagatsis, A. (2007). Students' improper proportional reasoning: A result of the epistemological obstacle of "linearity". Educational Psychology, 27(1), 75-92. https://doi.org/10.1080/01443410601061462

National Council of Teachers of Mathematics (2000). Principles and standards for school mathematics. Reston, VA: Author.

Orrill, C. H., \& Brown, R. E. (2012). Making sense of double number lines in professional development: Exploring teachers' understandings of proportional relationships. Journal of Mathematics Teacher Education, 15(5), 381-403. https://doi.org/10.1007/s10857$\underline{012-9218-\mathrm{Z}}$

Patton, M. Q. (2005). Qualitative research. John Wiley \& Sons, Ltd.

Riley, K. R. (2010). Teachers' understanding of proportional reasoning. In P. Brosnan, D. B. Erchick, \& L. Flevares (Eds.), Proceedings of the 32nd annual meeting of the North American Chapter of the International Group for the Psychology of Mathematics Education (pp. 1055-1061). Columbus, OH: The Ohio State University

Van Dooren, W., De Bock, D., \& Verschaffel, L. (2010). From addition to multiplication... and back: The development of students' additive and multiplicative reasoning skills. Cognition and Instruction, 28, 360-381. https://doi.org/10.1080/07370008.2010.488306 